\title{
ANALISIS PERHITUNGAN HARGA POKOK PRODUKSI TEH SEDAP WANGI MENGGUNAKAN METODE HARGA POKOK PROSES PADA PT. SARIWANGI A.E.A
}

\section{THE PRODUCTION COST ANALYSIS OF SEDAP WANGI TEA USING COST OF PROCESS METHOD AT PT. SARIWANGI A.E.A}

\author{
M.N. Afif, D.R.Rahmawati \\ Program Studi Akuntansi Fakultas Ekonomi Universitas Djuanda Bogor \\ Jl. Tol Ciawi No. 1, Kotak Pos 35, Kode Pos 16720, Telp/Fax : (0251) 8245155 \\ Email: m.nur.afif@unida.ac.id, dewirahayurahmawati@gmail.com
}

\begin{abstract}
This research aims to determine production cost of Sedap Wangi tea using by cost method at PT. Sariwangi A.E.A. TheCalculation of cost production using by cost method process is collected in a production department. Cost method process used weighted average method. Methods and tools of the data collection by interview and collection of data obtained directly from the company, and the result of this research calculation the cost production by using cost method process Produce cost of production is same with the calculation by the company, so it can be said that the calculation of cost production at PT. Sariwangi A.E.A complies done. Calculation of the cost production is influenced by the product is lost in the process and load of cost. Cost of the highest production at PT. Sariwangi A.E.A contained in quartile 4 the period October-Decemberbecause in that period decreased production yield and many products lost in the process. Cost of production in the quartile 4 of $\mathrm{Rp} \mathrm{54.742.} \mathrm{Lowest}$ Cost of production happen in quartile 2 period April-june, because the result of increased production in the period and not a lot of product is lost in the process. Cost of production in the quartile 2 of Rp 48.004 .
\end{abstract}

Key words : Cost of Production, Cost of Process Method

\section{ABSTRAK}

Penelitian ini bertujuan untuk mengetahui harga pokok produksi teh sedap wangi dengan menggunakan metode harga pokok proses pada PT. Sariwangi A.E.A. Perhitungan harga pokok produksi menggunakan metode harga pokok proses dikumpulkan dalam satu departemen produksi. Metode harga pokok proses yang digunakan metode rata-rata tertimbang. Metode dan alat pengumpulan data dilakukan dengan cara wawancara, dan pengumpulan data diperoleh langsung dari perusahaan, dengan hasil penelitian adalah perhitungan harga pokok produksi dengan menggunakan metode harga pokok proses menghasilkan harga pokok produksi yang sama dengan perhitungan yang dilakukan oleh perusahaan, sehingga dapat dikatakan bahwa perhitungan harga pokok produksi pada PT. Sariwangi A.E.A telah sesuai dilakukan. Perhitungan harga pokok produksi dipengaruhi oleh produk hilang dalam proses dan pembebanan biaya. Harga pokok produksi tertinggi pada PT. Sariwangi A.E.A terdapat pada quartil 4 yakni periode OktoberDesember dikarenakan pada periode tersebut hasil produksi menurun dan banyak produk hilang dalam proses. Harga pokok produksi pada quartil 4 sebesar Rp 54.742. Harga pokok produksi terendah terjadi pada quartil 2 periode April-Juni dikarenakan hasil produksi pada periode tersebut meningkat dan tidak terjadi banyak produk hilang dalam proses. Harga pokok produksi pada quartil 2 sebesar Rp 48.004.

Kata Kunci: Harga Pokok Produksi, Metode Harga Pokok Proses 


\section{PENDAHULUAN}

Pertumbuhan perekonomian global mengakibatkan kebutuhan akan barang dan jasa meningkat, sehinggga perusahaan bersaing untuk dapat menghasilkan produk yang berkualitas dan dapat diterima oleh masyarakat. Permasalahaan tersebut menjadi tantangan bagi manajemen perusahaan untuk dapat meningkatkan efektivitas serta efisiensi operasional perusahaan. Perusahaan dapat merencanakan, mengorganisasikan serta mengevaluasi kegiatan perusahaan guna meningkatkan efektivitas dan efisiensi perusahaan. Dalam kegiatan usahanya perusahaan memiliki tujuan untuk meningkatkan produktivitas dan laba yang diperoleh perusahaan. Dilihat dari segi usaha yang dihasilkan perusahaan digolongkan menjadi tiga yaitu perusahaan dagang, perusahaan jasa dan perusahaan manufaktur.

Perusahaan manufaktur adalah perusahaan yang jenis kegiatannya mengolah bahan baku menjadi barang dalam proses kemudian menjadi barang yang siap untuk dipasarkan. Dalam mengolah produk perusahaan manufaktur memerlukan biayabiaya yang perlu diperhatikan, sehingga produk yang dihasilkan siap untuk dipasarkan. Biaya yang dikeluarkan disebut dengan biaya produksi. (Suprajitno, 2011)

Biaya produksi merupakan suatu beban yang dikeluarkan oleh perusahaan dalam menghasilkan produk atau jasa yang bermanfaat bagi manusia.Proses perhitungan biaya produksi dalam perusahaan merupakan hal penting karena dalam melakukan proses produksi tentunya akan mengeluarkan biaya yang besar. Biaya-biaya yang perlu diperhitungkan diantaranya biaya bahan baku, biaya tenaga kerja langsung, dan biaya overhead pabrik. Ketiga unsur biaya tersebut merupakan informasi yang diperlukan menghitung harga pokok produksi.

Harga pokok produksi merupakan komponen terpenting untuk menilai tingkat keberhasilan suatu perusahaan. Menurut Mulyadi (2016:10) mengungkapkan bahwa harga pokok produksi atau yang sering disebut harga pokok adalah pengorbanan sumber ekonomi yang diumur dalam satuan yang telah terjadi atau kemungkinan terjadi untuk memperoleh keuntungan. Berdasarkan definisi diatas dapat diambil kesimpulan bahwa harga pokok produksi adalah suatu cara yang dilakukan perusahaan dalam memperoleh keuntungan dengan memperhitungkan biayabiaya yang diperlukan dalam menghasilkan sebuah produksi.

Perhitungan harga pokok dilakukan dengan menjumlahkan seluruh unsur biaya produksi, sedangkan harga pokok produksi per unit ditentukan dengan membagi seluruh total biaya produksi dengan volume produksi yang dihasilkan atau yang diharapkan akan dihasilkan. Cara seperti ini yang harus digunakan apabila berhubungan dengan prinsip akuntansi, mempengaruhi, baik jumlah harga pokok produk maupun cara penyajiannya dalam laporan rugi laba. Dalam memperhitungkan unsur-unsur biaya ke dalam harga pokok produksi terdapat dua pendekatan yaitu full costing dan variable costing. Full costing merupakan metode penentuan harga pokok produksi yang memperhitungkan semua unsur biaya produksi kedalam harga pokok produksi yang terdiri dari biaya bahan baku, biaya tenaga kerja langsung dan biaya overhead pabrik baik yang berperilaku variabel maupun tetap, sedangkan biaya variable costing merupakan metode penentuan harga pokok produksi yang hanya memperhitungkan biaya produksi yang berperilaku variabel kedalam harga pokok produksi yang terdiri biaya bahan baku, biaya tenaga kerja langsung, dan biaya overhead pabrik variabel. (Lasena, 2013)

Penentuan harga pokok produksi dibutuhkan dalam perusahaan sebagai alat dalam mengukur kemampuan perusahaan dalam meningkatkan laba/ keuntungan. pentingnya penentuan harga pokok produksi mengharuskan perusahaan dapat memperhitungkan harga pokok produksi dengan agar perusahaan tidak menderita kerugian di masa yang akan datang. Pengumpulan harga pokok produksi dapat ditentukan dengan dua metode yaitu metode harga pokok pesanan dan metode harga pokok proses. Metode harga pokok pesanan digunakan oleh perusahaan yang melakukan produksi berdasarkan pesanan sedangkan metode harga pokok proses dilakukan oleh perusahaan yang memproduksi secara terus menerus.

Metode harga pokok proses mempunyai peranan yang penting dalam penentuan harga pokok produksi dengan memperhitungkan harga pokok per departemen. Mulyadi (2016:63) Metode harga pokok proses adalah 
metode pengumpulan harga pokok (biaya produksi) yang berdasarkan atas proses atau departemen untuk suatu periode tertentu, biasanya satu bulan. Biaya bahan baku, biaya tenaga kerja langsung dan biaya overhead pabrik yang dibebankan pada rekeningrekening barang dalam proses setiap departemen. Pada setiap akhir periode, total harga pokok (biaya produksi) yang terjadi pada satu departemen dibagi dengan jumlah unit yang selesai di produksi dan menghasilkan harga pokok per unit departemen yang bersangkutan.

Menentukan harga pokok proses dalam perusahaan memerlukan perhitungan biaya produksi per satuan produk yang dihasilkan oleh satu departemen, menghitung biaya per satuan produk diperlukan penentuan unit ekuivalen. Unit ekuivalen dipengaruhi oleh jumlah produk yang ditransfer ke departemen selanjutnya atau ke gudang, tingkat penyelesaian produk dalam proses pada akhir periode dan ada atau tidaknya produk hilang dalam proses

PT. Sariwangi A.E.A (Agricultural Estate Agency) termasuk kedalam perusahan manufaktur yang memproduksi bahan baku teh menjadi barang jadi teh kantong dalam kemasan. Produk yang dihasilkan oleh PT. Sariwangi A.E.A dihitung hanya dengan satu departemen. Mulai dari pengolahan bahan baku, barang dalam proses hingga barang jadi diperhitungkan pada satu departemen saja. Pada akhir periode akan diperhitungkan sebagai harga pokok produksi.

PT. Sariwangi A.E.A memproduksi teh kantong dalam kemasan dengan brand image produk teh sariwangi. PT. Sariwangi A.E.A memiliki pangsa pasar yang cukup luas dikalangan masyarakat dengan harga yang kompetitif sariwangi mampu bersaing dengan perusahaan sejenis nya. Selain itu tidak hanya teh sariwangi yang menjadi brand image masih terdapat beberapa teh dalam kemasan lainnya yang ingin diperkenalkan oleh perusahaan salah satu nya adalah teh sedap wangi. Teh sedap wangi merupakan teh yang diproduksi oleh perusahaan dengan harapan dapat mengikuti keberhasilan teh sariwangi sehingga dapat bersaing dengan merek teh lainnya. Kegiatan produksi teh sedap wangi dilakukan secara terus menerus dengan memperhitungkan harga pokok produksi, perhitungan harga pokok produksi teh sedap wangi dilakukan dengan mengumpulkan semua biaya yang dikeluarkan pada saat memproduksi teh sedap wangi tersebut. Agar lebih efektif dalam perhitungan harga pokok produksi sesuai jenis kegiatan produksi maka metode yang dapat digunakan adalah metode pengumpulan harga pokok proses.

Harga pokok proses merupakan metode pengumpulan perhitungan harga pokok produksi per satuan dihitung dengan membagi total biaya produksi dengan jumlah produk yang dihasilkan. Pada kegiatan produksi yang dihasilkan teh sedap wangi mengalami penurunan hasil produksi yang akan berdampak pada besarnya biaya yang akan dikeluarkan. Hasil produksi yang dihasilkan oleh PT. Sariwangi A.E.A mengalami fluktuasi selama tahun 2016. Berikut ini Data yang menunjukkan volume produksi teh sedap wangi pada tahun 2016:

Tabel 1. Volume Produksi Teh Sedap Wangi Tahun 2016

\begin{tabular}{lc}
\hline \multicolumn{1}{c}{ Bulan } & Volume Produksi \\
\hline Januari - Maret & 242.792 FIB \\
April - Juni & 339.139 FIB \\
Juli -September & 205.405 FIB \\
Oktober - Desember & 107.207 FIB \\
\hline Jumlah & 894.543 FIB \\
\hline
\end{tabular}

Sumber: PT. Sariwangi A.E.A (Data diolah, 2016)

Berdasarkan Tabel 1. PT. Sariwangi A.E.A. melakukan perhitungan volume produksi per quartil (pertiga bulan) dan volume produksi teh sedap wangi di tahun 2016 mengalami penurunan tepatnya dari quartil 2 ke quartil 3 dan dari quartil 3 ke quartil 4 . Satuan hasil produksi untuk teh sedap wangi adalah FIB (kardus teh) satuan kardus berisi 48 pack teh kantong dalam kemasan. Pada volume produksi periode April-Juni teh sedap wangi mengalami kenaikan, hasil produksi tersebut sebesar 339.139 FIB teh produksi tinggi dikarenakan permintaan teh pada periode tersebut mengalami peningkatan dan pada periode tersebut produk hilang dalam proses relatif sedikit sehingga pada periode tersebut mengalami peningkatan hasil produksi. 
Penurunan hasil produksi terjadi pada periode selanjutnya dikarenakan banyaknya produk hilang dalam proses karena mesin packaging kurang optimal dalam produksinya sehingga pada saat packaging terdapat beberapa produk hilang dalam proses. Banyaknya produk hilang dalam proses akan mengakibatkan harga pokok produksi yang tinggi karena biaya yang diserap pada produk hilang tersebut akan membuat biaya yang dikeluarkan pada periode tersebut tinggi. Volume produksi terendah terjadi pada quartil 4 (Oktober-Desember) yaitu sebanyak 107.207 FIB.

Permasalahan produk barang hilang dalam proses serta pembebanan biaya yang dikeluarkan oleh PT. Sariwangi A.E.A merupakan masalah dalam menentukan harga pokok produksi dikarenakan produk hilang dalam proses telah menyerap biaya dan akan berpengaruh pada volume produksi yang dihasilkan serta harga pokok yang dihasilkan tinggi. Ketika harga pokok produksi yang dihasilkan tinggi maka volume produksi yang dihasilkan perusahaan akan menurun dan akan mengurangi keuntungan yang diperoleh oleh perusahaan serta tidak tercapainya target volume produksi yang diinginkan oleh perusahaan. Oleh karena itu, perusahaan perlu menyusun strategi yang dapat meningkatkan volume produksi sehingga perusahaan mampu menentukan harga pokok produksi khusunya teh sedap wangi dengan tepat, serta memperoleh keuntungan yang diharapkan.

Penggolongan biaya Menurut Mulyadi (2016:13) biaya digolongkan dengan berbagai macam cara. Biaya dapat digolongkan menurut:

1. Objek Pengeluaran

Dalam cara penggolongan ini, nama objek pengeluaran merupakan dasar penggolongan biaya.

2. Fungsi Pokok Dalam Perusahaan

Dalam perusahaan manufaktur, ada tiga fungsi pokok yaotu fungsi produksi, fungsi pemasaran, dan fungsi administrasi \& umum. Oleh karena itu dalam perusahaan manufaktur, biaya dapat dikelompokan menjadi tiga kelompok yaitu:

a. Biaya produksi merupakan biaya-biaya yang terjadi untuk mengolah bahan baku menjadi produk jadi yang siap untuk dijual. b. Biaya pemasaran merupakan biayabiaya yang terjadi untuk melaksanakan kegiatan pemasaran produk.

c. Biaya administrasi dan umum merupakan biaya-biaya untuk mengkoordinasi kegiatan produksi dan pemasaran produk.

3. Hubungan Biaya Dengan Sesuatu Yang Dibiayai

Sesuatu yang dibiayai dapat berupa produk atau departemen. Dalam hubungannya dengan sesuatu yang dibiayai, biaya dapat dikelompokkan menjadi 2 ( dua) golongan:

a. Biaya langsung (direct cost) biaya langsung adalah biaya yang terjadi, yang penyebab satu-satunya adalah karena adanya sesuatu yang dibiayai. Jika sesuatu yang dibiayai itu tidak ada, maka biaya langsung ini tidak akan terjadi.

b. Biaya tidak langsung biaya tidak langsung adalah biaya yang terjadinya tidak hanya disebabkan oleh sesuatu yang dibiayai. Biaya tidak langsung dalam hubungannya dengan produk disebut dengan istilah biaya produksi tidak langsung atau biaya overhead pabrik (factory overhead cost). Biaya ini tidak mudah diidentifikasikan dengan produk tertentu. Dalam hubungannya dengan departemen, biaya tidak langsung adalah biaya yang terjadi di departemen tetapi manfaatnya dinikmati oleh lebih dari satu departemen.

4. Perilaku Biaya Dalam Hubungannya Dengan Perubahan Volume Kegiatan

Dalam hubungannya dengan perubahan volume aktivitas, biaya dapat digolongkan menjadi:

a. Biaya variabel merupakan biaya yang jumlah totalnya berubah sebanding dengan perubahan volume kegiatan.

b. Biaya semi variabel merupakan biaya yang berubah tidak sebanding dengan perubahan volume kegiatan. Biaya semi variabel mengandung unsur biaya tetap dan unsur biaya variabel.

c. Biaya semifixed merupakan biaya yang tetap untuk tingkat volume kegiatan tertentu dan berubah dengan jumlah yang konstan pada volume produksi tertentu

d. Biaya tetap merupakan biaya yang 
e. jumlah totalnya tetap dalam kisar volume kegiatan tertentu contoh biaya tetap adalah gaji direktur produksi.

5. Jangka Waktu Manfaatnya

Atas dasar jangka waktu dan manfaatnya, biaya dibagi menjadi dua yaitu: pengeluaran modal dan pengeluaran pendapatan

a. Pengeluaran modal (capital expenditures) pengeluaran modal adalah biaya yang mempunyai manfaat lebih dari satu periode akuntansi (biasanya periode akuntansi adalah satu tahun kalender). Pengeluaran modal ini pada saat terjadinya dibebankan sebagai kos aktiva, dan dibebankan dalam tahun-tahun yang menikmati manfaatnya dengan cara didepresiasi, diamortisasi, atau dideplesi.

b. Pengeluaran pendapatan merupakan biaya yang hanya mempunyai manfaat dalam periode akuntansi terjadinya pengeluaran tersebut.

Penggolongan biaya perlu diketahui untuk dapat memperhitungkan harga pokok produksi . Menurut Bustami dan Nurlaela sesuai, serta bagi lingkungan akademik penelitian ini diharapkan mampu memberikan kontribusi atau bahan referensi bagi peneliti selanjutnya.

\section{METODE PENELITIAN}

Penelitian ini menggunakan Data-data mengenai harga pokok produksi dengan metode harga pokok proses yang telah dilakukan oleh perusahaan dengan periode pengamatan tahun 2016. Desain penelitian yang dipergunakan dalam penelitian ini adalah penelitian deskriptif komparatif. Jenis data yang digunakan adalah data kuantatif dengan sumber data primer dan sekunder unit analisis dengan memperhitungkan data produksi, unit ekuivalen, unit cost, dan perhitungan harga pokok produksi.

\section{HASIL PENELITIAN DAN PEMBAHASAN} Perhitungan harga pokok Produksi Teh Sedap Wangi
(2006:60) Harga Pokok produksi adalah kumpulan biaya produksi yang terdiri dari bahan baku langsung, tenaga kerja langsung, dan biaya overhead pabrik ditambah persediaan produk dalam proses awal dan dikurang persediaan produk dalam proses akhir.

Pengumpulan harga pokok produksi dapat dilakukan dengan dua cara yaitu: metode harga pokok pesanan dan metode harga pokok proses metode harga pokok pesanan adalah metode yang digunakan berdasarkan pesanan, sedangkan metode harga pokok proses Purwaji dan Wibowo (2009:103) mengatakan bahwa harga pokok proses adalah proses produksi yang terjadi di perusahaan manufaktur dapat dilakukan melalui beberapa departemen dan setiap departemen tersebut melakukan kegiatan operasi tertentu untuk menyelesaikan produk.

Hasil penelitian ini diharapkan dapat memberikan manfaat bagi penulis lebih memahami tentang akuntansi biaya, harga pokok produksi dan harga pokok proses, bagi perusahaan memberikan informasi dalam memperhitungkan harga pokok produksi dengan metode harga pokok proses yang

PT. Sariwangi A.E.A memperhitungkan harga pokok produksi untuk teh sedap wangi dilakukan dengan menjumlahkan semua biaya yang telah terjadi selama proses produksi dan membaginya dengan hasil produksi yang dihasilkan. Berikut ini data yang diperhitungkan dalam perhitungan harga pokok produksi.

1. Bahan Baku dan Bahan Penolong

Bahan baku adalah komponen penting dalam suatu pembuatan produksi, karena proses produksi dilakukan untuk mengolah bahan baku menjadi barang yang siap untuk dipasarkan sedangkan bahan penolong merupakan bahan-bahan yang sifatnya membantu atau mendukung proses produksi. Berikut bahan baku dan bahan penolong yang digunakan pada proses produksi PT. Sariwangi A.E.A dalam menghasilkan produksi teh sedap wangi yang dapat dilihat pada tabel 2 dibawah ini.

Tabel 2. Bahan Baku dan Bahan Penolong Teh Sedap Wangi

\begin{tabular}{llll}
\hline No. & Bahan Baku & Bahan Penolong & Deskripsi \\
\hline 1 & $\begin{array}{l}\text { Thread 12/2 } \\
\text { maisa untwist }\end{array}$ & $\begin{array}{l}\text { Bahan baku utama berupa benang yang } \\
\text { dimasukkan dalam pembuatan teh }\end{array}$ \\
\hline 2 & & Tape uli cyan (biru) & Bahan baku penolong berupa lakban yang
\end{tabular}




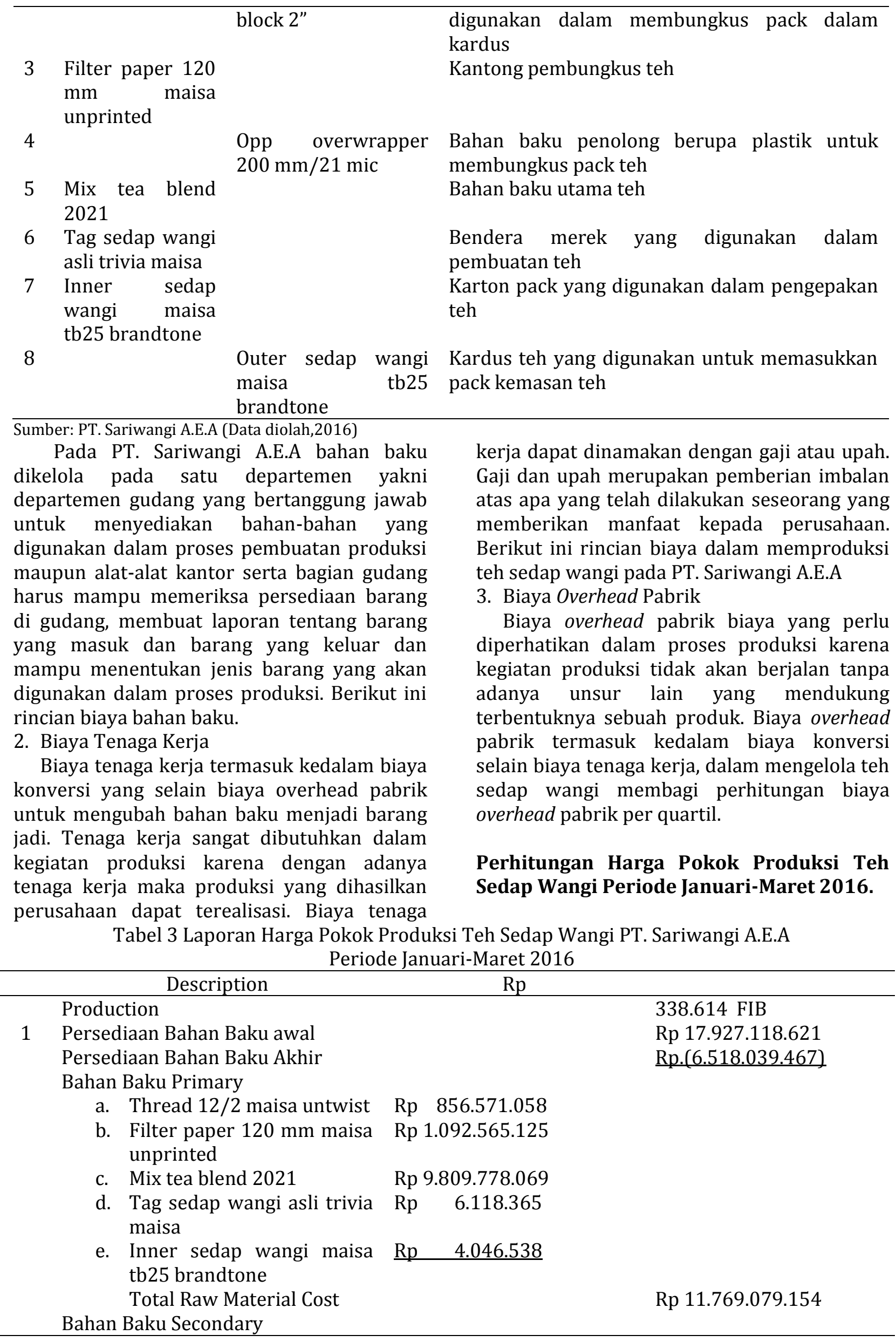




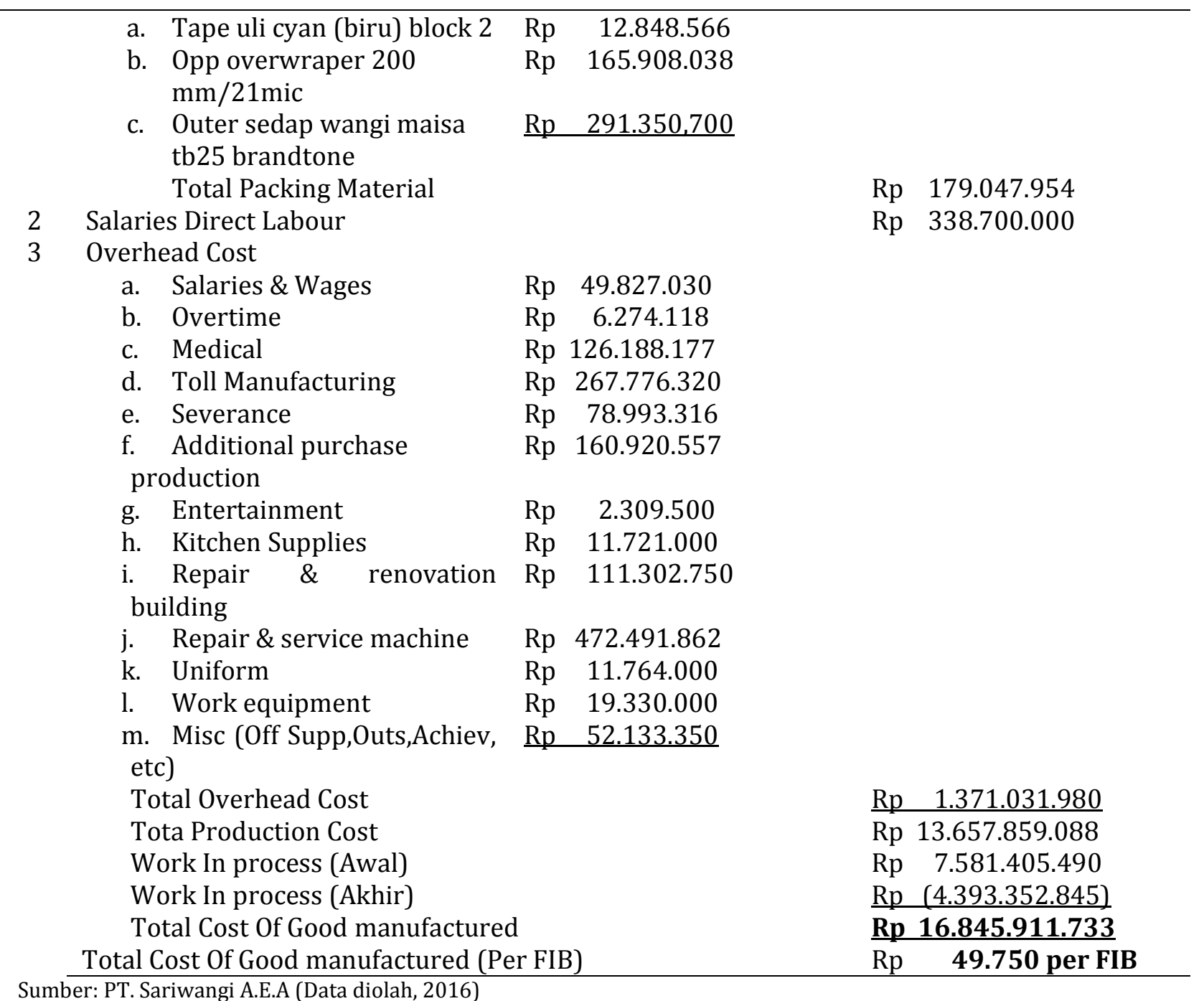
Sumber: PT. Sariwangi A.E.A (Data diolah, 2016)

Berdasarkan laporan harga pokok sebesar Rp 49.750. Perhitungan Harga Pokok produksi pada quartil 1 periode (Januari- Produksi Teh Sedap Wangi Periode April-Juni Maret) dapat dijelaskan bahwa harga pokok 2016. per FIB/per duz untuk tehsedap wangi adalah

Tabel 4 Laporan Harga Pokok Produksi Teh Sedap wangi PT. Sariwangi A.E.A

Periode April-Juni 2016

\begin{tabular}{|c|c|c|c|c|}
\hline No & Description & \multicolumn{2}{|r|}{$\mathrm{Rp}$} & \multirow{2}{*}{473.508 FIB } \\
\hline \multirow{14}{*}{1} & Production & & & \\
\hline & Persediaan Bahan Baku Awal & & & 21.374.343.069 \\
\hline & Persediaan Bahan Baku Akhir & & & 6.158 .039 .467 \\
\hline & Bahan Baku Primary & & & \\
\hline & a. Thread $12 / 2$ maisa untwist & $\mathrm{Rp}$ & 1.196.658.792 & \\
\hline & $\begin{array}{l}\text { b. Filter paper } 120 \mathrm{~mm} \text { maisa } \\
\text { unprinted }\end{array}$ & $\mathrm{Rp}$ & 1.526.350.500 & \\
\hline & c. Mix tea blend 2021 & $\mathrm{Rp}$ & 3.704 .592 .356 & \\
\hline & d. Tag sedap wangi asli trivia maisa & $\mathrm{Rp}$ & 8.547 .563 & \\
\hline & $\begin{array}{l}\text { e. Inner sedap wangi maisa tb25 } \\
\text { brandtone }\end{array}$ & & 5.653 .150 & \\
\hline & Total Bahan Baku Primary & & & Rp 16.441.802.361 \\
\hline & Bahan Baku Secondary & & & \\
\hline & a. Tape uli cyan (biru) block 2 “ & $\mathrm{Rp}$ & 17.949 .882 & \\
\hline & b. Opp overwraper $200 \mathrm{~mm} / 21 \mathrm{mic}$ & $\mathrm{Rp}$ & 231.779 .150 & \\
\hline & c. Outer sedap wangi maisa tb25 & $\mathrm{Rp}$ & $407.026,800$ & \\
\hline
\end{tabular}




\begin{tabular}{|c|c|c|c|c|c|}
\hline \multicolumn{6}{|c|}{ brandtone } \\
\hline & Total Bahan Baku Secondary & & & $\mathrm{Rp}$ & 250.136 .059 \\
\hline 2 & Salaries Direct Labour & & & $\mathrm{Rp}$ & 383.400 .000 \\
\hline 3 & Overhead Cost & & & & \\
\hline & a. Salaries \& Wages & $\mathrm{Rp}$ & 52.771 .755 & & \\
\hline & b. Overtime & $\mathrm{Rp}$ & 14.545 .201 & & \\
\hline & c. Medical & $\mathrm{Rp}$ & 94.444 .242 & & \\
\hline & d. Toll Manufacturing & & - & & \\
\hline & e. Severance & $\mathrm{Rp}$ & 27.145 .048 & & \\
\hline & f. Additional purchase production & $\mathrm{Rp}$ & 74.510 .020 & & \\
\hline & g. Entertainment & $\mathrm{Rp}$ & 3.890 .202 & & \\
\hline & h. Kitchen Supplies & $\mathrm{Rp}$ & 15.908 .500 & & \\
\hline & i. Repair \& renovation building & $\mathrm{Rp}$ & 46.681 .750 & & \\
\hline & j. Repair \& service machine & $\mathrm{Rp}$ & 432.187 .573 & & \\
\hline & k. Uniform & $\mathrm{Rp}$ & 134.400 .000 & & \\
\hline & 1. Work equipment & $\mathrm{Rp}$ & 40.504 .842 & & \\
\hline & m. Misc (Off Supp,Outs,Achiev, etc) & $\underline{\mathrm{Rp}}$ & 82.579 .848 & & \\
\hline & Total Overhead Cost & & & & $\mathrm{Rp} \quad 1.219 .568 .981$ \\
\hline & Tota Production Cost & & & & Rp 18.294.907.401 \\
\hline & Work In process (awal) & & & & Rp 10.484.946.592 \\
\hline & Work In process (akhir) & & & & $\operatorname{Rp}(6.049 .144 .469)$ \\
\hline & Total Cost Of Good Manufactured & & & & Rp 22.730.709.524 \\
\hline & $\begin{array}{l}\text { Total Cost Of Good Manufactured } \\
\text { (per FIB) }\end{array}$ & & & & $\mathrm{Rp} \quad 48.004$ FIB \\
\hline
\end{tabular}

Sumber: PT. Sariwangi A.E.A (Data diolah, 2016)

Berdasarkan laporan harga pokok produksi pada quartil 2 periode (April-Juni) 2016 dapat dijelaskan bahwa harga pokok per FIB/per duz

untuk teh sedap wangi adalah sebesar $\mathrm{Rp}$ 48.004

Perhitungan Harga Pokok Produksi Teh Sedap Wangi Periode Juli-September 2016.

Tabel 5 Laporan Harga Pokok Produksi Teh Sedap Wangi PT. Sariwangi A.E.A

Periode Juli-September 2016

\begin{tabular}{|c|c|c|c|c|c|}
\hline $\begin{array}{c}\text { No } \\
1\end{array}$ & Description & \multicolumn{2}{|r|}{$\mathrm{Rp}$} & \multirow{2}{*}{\multicolumn{2}{|c|}{ 286. $745 \mathrm{FIB}$}} \\
\hline \multirow{13}{*}{1} & Production & & & & \\
\hline & Persediaan Bahan Baku Awal & & & $\mathrm{Rp}$ & 12.943 .791 .203 \\
\hline & Persediaan Bahan Baku Akhir & & & $\mathrm{Rp}$ & $(2.987 .028 .739)$ \\
\hline & Bahan Baku Primary & & & & \\
\hline & $\begin{array}{lll}\text { a. Thread } & 12 / 2 \text { maisa } \\
\text { untwist } & \end{array}$ & $\mathrm{Rp}$ & 724.667 .958 & & \\
\hline & $\begin{array}{l}\text { b. Filter paper } 120 \mathrm{~mm} \\
\text { maisa unprinted }\end{array}$ & $\mathrm{Rp}$ & 924.321 .375 & & \\
\hline & c. Mix tea blend 2021 & $\mathrm{Rp}$ & 8.299.173.519 & & \\
\hline & $\begin{array}{l}\text { d. Tag sedap wangi asli trivia } \\
\text { maisa }\end{array}$ & $\mathrm{Rp}$ & 5.176 .200 & & \\
\hline & $\begin{array}{l}\text { e. Inner sedap wangi maisa } \\
\text { tb25 brandtone }\end{array}$ & $\mathrm{Rp}$ & 3.423 .413 & & \\
\hline & $\begin{array}{l}\text { Total Bahan Baku Primary } \\
\text { Bahan Baku Secondary }\end{array}$ & & & $\mathrm{Rp}$ & 9.956 .762 .464 \\
\hline & $\begin{array}{l}\text { a. Tape uli cyan (biru) block } \\
2 \text { “ }\end{array}$ & $\mathrm{Rp}$ & 10.870 .019 & & \\
\hline & $\begin{array}{l}\text { b. Opp overwraper } 200 \\
\mathrm{~mm} / 21 \mathrm{mic}\end{array}$ & $\mathrm{Rp}$ & 140.359 .913 & & \\
\hline & $\begin{array}{l}\text { c. Outer sedap wangi maisa } \\
\text { tb25 brandtone }\end{array}$ & $\mathrm{Rp}$ & $246.485,700$ & & \\
\hline
\end{tabular}




\begin{tabular}{|c|c|c|c|c|c|}
\hline \multicolumn{6}{|c|}{ Secondary } \\
\hline 2 & Salaries Direct Labour & & & $\mathrm{Rp}$ & 338.700 .000 \\
\hline 3 & Overhead Cost & & & & \\
\hline & a. Salaries \& Wages & $\mathrm{Rp}$ & 53.947 .506 & & \\
\hline & b. Overtime & $\mathrm{Rp}$ & 80.998 .086 & & \\
\hline & c. THR/THN & $\mathrm{Rp}$ & 149.611 .683 & & \\
\hline & d. Medical & $\mathrm{Rp}$ & 109.843 .203 & & \\
\hline & e. Toll Manufacturing & $\mathrm{Rp}$ & 34.170 .625 & & \\
\hline & f. Severance & $\mathrm{Rp}$ & 12.040 .000 & & \\
\hline & g. Additional purchase production & $\mathrm{Rp}$ & 81.797 .525 & & \\
\hline & h. Entertainment & $\mathrm{Rp}$ & 5.607 .700 & & \\
\hline & i. Kitchen Supplies & $\mathrm{Rp}$ & 19.639 .500 & & \\
\hline & j. Repair \& renovation building & $\mathrm{Rp}$ & 17.231 .000 & & \\
\hline & k. Repair \& service machine & $\mathrm{Rp}$ & 603.280 .718 & & \\
\hline & 1. Uniform & & & & \\
\hline & m. Work equipment & $\mathrm{Rp}$ & 53.108 .182 & & \\
\hline & n. Misc (Off Supp,Outs,Achiev, etc) & $\mathrm{Rp}$ & 84.291 .152 & & \\
\hline & Total Overhead Cost & & & $\underline{\mathrm{Rp}}$ & 1.421 .723 .935 \\
\hline & Tota Production Cost & & & $\mathrm{Rp}$ & 11.719 .051 .134 \\
\hline & Work In Process (Awal) & & & $\mathrm{Rp}$ & 5.727 .434 .049 \\
\hline & Work In Process (Akhir) & & & $\mathrm{Rp}$ & $(3.386 .043 .928)$ \\
\hline & Total Cost Of Good Manufactured & & & $\underline{\mathrm{Rp}}$ & 14.240 .054 .939 \\
\hline & $\begin{array}{l}\text { Total Cost Of Good Manufactured } \\
\text { (per FIB) }\end{array}$ & & & $\mathrm{Rp}$ & 49.661 per FIB \\
\hline
\end{tabular}

Sumber: PT. Sariwangi A.E.A (Data diolah, 2016)

Berdasarkan laporan harga pokok produksi pada quartil 3 periode (Juli-September) 2016 dapat dijelaskan bahwa harga pokok per FIB/per duz untuk teh sedap wangi adalah

Perhitungan Harga Pokok Produksi Teh Sedap Wangi Periode Oktober-Desember 2016. sebesar Rp 49.661

Tabel 6 Laporan Harga Pokok Produksi Teh Sedap Wangi PT. Sariwangi A.E.A Periode Oktober-Desember 2016

\begin{tabular}{|c|c|c|c|c|}
\hline $\begin{array}{c}\text { No } \\
1\end{array}$ & Description & $\mathrm{Rp}$ & \multirow{2}{*}{\multicolumn{2}{|c|}{$149.661 \mathrm{FIB}$}} \\
\hline \multirow{15}{*}{1} & Production & & & \\
\hline & Persediaan Bahan Baku Awal & & & 6.755 .774 .925 \\
\hline & Persediaan Bahan Baku Akhir & & $\underline{\mathrm{Rp}}$ & $(1.559 .024 .983)$ \\
\hline & Bahan Baku Primary & & & \\
\hline & a. $\quad$ Thread $12 / 2$ maisa untwist & Rp $\quad 378.227 .178$ & & \\
\hline & $\begin{array}{l}\text { b. Filter paper } 120 \mathrm{~mm} \text { maisa } \\
\text { unprinted }\end{array}$ & Rp $\quad 482.432 .625$ & & \\
\hline & c. Mix tea blend 2021 & Rp 4.331.601.729 & & \\
\hline & $\begin{array}{l}\text { d. Tag sedap wangi asli trivia } \\
\text { maisa }\end{array}$ & $\mathrm{Rp} \quad 2.701 .623$ & & \\
\hline & $\begin{array}{l}\text { e. Inner sedap wangi maisa tb25 } \\
\text { brandtone }\end{array}$ & 1.786 .788 & & \\
\hline & Total Bahan Baku Primary & & $\mathrm{Rp}$ & 5.196 .749 .942 \\
\hline & Bahan Baku Secondary & & & \\
\hline & a. Tape uli cyan (biru) block 2 " & 5.673 .408 & & \\
\hline & $\begin{array}{l}\text { b. Opp overwraper } 200 \\
\mathrm{~mm} / 21 \mathrm{mic}\end{array}$ & 73.258 .288 & & \\
\hline & $\begin{array}{l}\text { c. Outer sedap wangi maisa tb25 } \\
\text { brandtone }\end{array}$ & Rp $\quad 128.648,700$ & & \\
\hline & Total Bahan Baku Secondary & & & 79.660 .344 \\
\hline 2 & Salaries Direct Labour & & & 319.860 .000 \\
\hline
\end{tabular}


Overhead Cost
a. Salaries \& Wages
Rp $\quad 62.583 .824$
b. Overtime
Rp $\quad 10.804 .490$
c. Medical
Rp 17.593.174
d. Toll Manufacturing
Rp $\quad 6.597 .500$
e. Severance
Rp $\quad 42.866 .736$
f. Additional production
g. Entertainment
h. Kitchen Supplies
purchase
$\mathrm{Rp} \quad 61.740 .000$
i. Repair \& renovation building
Rp $\quad 4.481 .100$
Rp $\quad 23.986 .600$
j. Repair \& service machine
k. Uniform
l. Work equipment
Rp $\quad 22.458 .000$
Rp 522.280.089
m. Misc (Off Supp,Outs,Achiev,
Rp $\quad 81.945 .449$
Rp $\quad 45.029 .000$ etc)

Total Overhead Cost

Rp $\quad 1.009 .366 .012$

Rp 6.605.636.298

Tota Production Cost

Rp $\quad 3.725 .399 .947$

Work In process (Awal)

Rp (2.138.153.253)

Work In Process (Akhir)

Rp 8.192.882.992

Total Cost Of Good

Rp 54.742 per/FIB

Sumber: PT. Sariwangi A.E.A (Data diolah, 2016)

Berdasarkan laporan harga pokok produksi pada quartil 4 periode (Oktober-Desember) 2016 dapat dijelaskan bahwa harga pokok per FIB/per duz untuk teh sedap wangi adalah sebesar Rp 54.742

\section{Faktor-Faktor Yang Mempengaruhi Perhitungan Harga Pokok Produksi}

Dalam perhitungan harga pokok produksi teh sedap wangi sering terjadi beberapa kendala yang mempengaruhi besar kecilnya harga pokok produksi diantaranya adalah sebagai berikut:

1. Pengaruh Produk Hilang Dalam Proses

Produk hilang dalam proses mempengaruhi perhitungan metode harga pokok proses pada PT. Sariwangi A.E.A dalam menentukan harga pokok produk per unit. Dalam memproduksi teh sedap wangi terdapat beberapa produk hilang dikarenakan produk yang rusak dan tidak dapat diperbaiki sehingga akan mempengaruhi hasil produksi pada periode yang bersangkutan sehingga apabila terjadi produk hilang biaya yang dikeluarkan tetap namun hasil produksi periode tersebut berkurang.

2. Pembebanan Biaya

Pembebanan biaya merupakan bagian dalam membuat laporan biaya produksi, pada dasarnya biaya produksi dikumpulkan

untuk memperhitungkan harga pokok per unit suatu produk selama periode tertentu. Informasi perhitungan biaya produksi tiap departemen yang dibebankan pada saat produksi dengan menjumlahkan semua biaya yang dikeluarkan pada periode yang bersangkutan serta biaya yang telah melekat pada barang dalam proses. Pembebanan biaya mempengaruhi pengumpulan metode harga pokok proses pada PT. Sariwangi A.E.A dikarenakan semakin besar biaya yang dikeluarkan maka akan semakin besar harga pokok produk yang dihasilkan.

Berdasarkan penjelasan diatas dapat dikatakan bahwa faktor-faktor yang mempengaruhi metode harga pokok proses adalah produk hilang dalam proses yang akan menambahkan harga pokok produk serta pembebanan biaya karena semakin besar biaya yang dikeluarkan pada tiap departemen makan semakin besar pula harga pokok produk yang dihasilkan. Jadi kedua faktor tersebut dapat dikatakan sebagai fakktor yang mempengaruhi harga pokok proses pada PT. Sariwangi A.E.A dalam menghasilkan teh sedap wangi.

\section{Perhitungan Harga Pokok Proses Periode Januari-Maret 2016}

1. Data Produksi Teh Sedap Wangi

Tabel 7 Data Produksi Teh Sedap Wangi Januari-Maret 


\begin{tabular}{lc}
\hline Keterangan & Departemen Pembuatan \\
\hline Barang dalam proses awal & 14.891 FIB \\
Produk yang dimasukkan dalam proses & 323.723 FIB \\
Barang selesai di transfer ke gudang & 242.792 FIB \\
Barang dalam proses akhir & 89.348 FIB \\
Produk Hilang di akhir proses & 6.474 FIB \\
\hline
\end{tabular}

Sumber: PT. Sariwangi A.E.A (Data diolah,2016)

Berdasarkan data diatas dapat dilihat bahwa PT. Sariwangi A.E.A pada bulan Januari-Maret 2016 produk dalam proses awal sebanyak 14. 891 FIB selanjutnya memasukkan produk dalam proses sebanyak 323.723 FIB dan barang yang telah diselesaikan atau barang jadi yang ditranfer ke gudang FG (finished good) adalah 242.792 FIB, barang dalam proses yang belum diselesaikan sebanyak 89.348 FIB dan terdapat barang hilang dalam proses produksi sebanyak 6.474 FIB. Pada proses produksi PT. Sariwangi A.E.A menerapkan tingkat penyelesaian produk untuk biaya bahan baku $100 \%$, biaya bahan penolong $50 \%$ dan biaya konversi (biaya tenaga kerja dan biaya overhead pabrik) $75 \%$

2. Perhitungan Unit Ekuivalensi.

Dalam menentukan metode harga pokok proses dibutuhkan perhitungan unit ekuivalensi. Berikut ini perhitungan unit ekuivalensi pada PT. Sariwangi A.E.A.

Tabel 8 Perhitungan Unit Ekuivalensi Periode Januari-Maret

\begin{tabular}{lccc}
\hline Keterangan & Biaya Bahan Baku & $\begin{array}{c}\text { Biaya Konversi } \\
(75 \%)\end{array}$ & $\begin{array}{c}\text { Biaya Bahan Penolong } \\
(50 \%)\end{array}$ \\
\hline Barang selesai & 242.792 & 242.792 & 242.792 \\
Barang dalam proses & 89.348 & 67.011 & 44.674 \\
\hline Jumlah & 332.140 & 309.803 & 287.466
\end{tabular}

Sumber: PT. Sariwangi A.E.A (Data diolah, 2016)

Berdasarkan perhitungan unit

ekuivalensi diatas menjelaskan bahwa jumlah

unit ekuivalen pada bahan baku sebesar

332.140, biaya konversi sebesar 309.803, dan biaya penolong sebesar 287.466

\section{Perhitungan Biaya Produksi Per Unit}

Tabel 9. Perhitungan Biaya Produksi Per Unit Periode Januari-Maret

\begin{tabular}{|c|c|c|c|c|}
\hline Jenis Biaya & $\begin{array}{l}\text { Biaya bahan baku } \\
\text { yang melekat }\end{array}$ & $\begin{array}{c}\text { Biaya yang dikeluarkan } \\
\text { dalam periode } \\
\text { sekarang }\end{array}$ & $\begin{array}{c}\text { Unit } \\
\text { Ekuivalensi }\end{array}$ & $\begin{array}{l}\text { Biaya per unit } \\
\text { produk } \\
\text { dihasilkan. }\end{array}$ \\
\hline $\begin{array}{l}\text { Biaya bahan } \\
\text { baku }\end{array}$ & Rp 2.706.914.018 & Rp 11.769 .079 .154 & 332.140 & Rp 43.584 \\
\hline $\begin{array}{l}\text { Biaya bahan } \\
\text { penolong }\end{array}$ & 41.181 .422 & 179.047 .954 & 287.466 & 766 \\
\hline $\begin{array}{l}\text { Biaya tenaga } \\
\text { kerja }\end{array}$ & 124.800 .000 & 338.700 .000 & 309.803 & 1.496 \\
\hline $\begin{array}{l}\text { Biaya overhead } \\
\text { pabrik }\end{array}$ & Rp $\quad 315.337 .355$ & 1.371 .031 .980 & 309.803 & Rp 5.443 \\
\hline Jumlah & Rp 3.188.232.795 & Rp 13.657 .859 .088 & 1.230 .212 & Rp 51.289 \\
\hline
\end{tabular}

Berdasarkan perhitungan biaya per unit diatas dapat dijelaskan bahwa biaya per unit untuk bahan baku adalah sebesar Rp 43.584, biaya bahan penolong sebesar Rp 766, biaya tenaga kerja langsung sebesar Rp 1.496 dan biaya overhead pabrik sebesar Rp 5.433 jadi biaya produksi per unit pada quartil 1 adalah Rp 51.289.

\section{Perhitungan Biaya Produksi.}

Tabel 10. Perhitungan Biaya Produksi Periode Januari- Maret

\begin{tabular}{|c|c|}
\hline Harga pokok Produk jadi (242.792 x 51.289) & Rp 12.452.558.888 \\
\hline $\begin{array}{l}\text { Barang dalam proses (89.348 FIB) } \\
\text { Biaya Bahan Baku }(100 \% \text { x 89.348) x } 43.584\end{array}$ & \\
\hline
\end{tabular}


Biaya Bahan Penolong (50\% x 89.348) x $766=$ Rp 34220.284

Biaya tenaga kerja langsung $(75 \% \times 89.348) \times 1.496=R p \quad 100.248 .456$

Biaya overhead pabrik (75\% $\times 89.348) \times 5.443=\mathrm{Rp} 364.740 .873$

Jumlah Biaya Produksi

$\underline{\text { Rp } \quad 4.393 .352 .845}$

Rp 16.845.911.733

Sumber: PT. Sariwangi A.E.A (Data Diolah, 2016)

Berdasarkan data diatas dapat dilihat bahwa jumlah biaya produksi sebesar Rp

sebanyak 338.614 dapat diperoleh harga 16.845.911.733 dibagi dengan hasil produksi pokok produksi sebesar Rp 49.750.

Tabel 11. Laporan Biaya Produksi Periode Januari-Maret

PT. Sariwangi A.E.A

Laporan Biaya Produksi

Periode Januari- Maret

Data Produksi

Barang dalam proses awal

14.891 FIB

Barang yang dimasukkan dalam proses

Produk jadi yang ditransfer ke gudang

Produk dalam proses akhir bulan, dengan tingkat

penyelesaian :

Biaya BB 100 \%dan penolong $50 \%$ biaya 89.348 FIB

Konversi $75 \%$

Produk yang hilang pada awal proses

$\underline{6.474 \mathrm{FIB}}$

Biaya yang dibebankan dalam departemen pembuatan:

Biaya bahan baku

Biaya bahan penolong

Biaya tenaga kerja

Biaya overhead pabrik

Jumlah biaya produksi departemen pembuatan

242.792 FIB

323.723 FIB

Perhitungan Biaya

Harga pokok produk selesai yang ditransfer ke gudang

Harga pokok persediaan produk dalam proses pada akhir periode

Biaya bahan baku

Biaya bahan penolong

Biaya tenaga kerja

Rp 34220.284

Biaya overhead pabrik

Total

Rp 14.758.152.576

Rp. 259. 378.324

$\mathrm{Rp} \quad 506.566 .544$

Rp 1.843.076.022

Rp 17.367.173.466

\section{$\underline{338.614 \mathrm{FIB}}$}

Per Kg

Rp 43.584

Rp 766

Rp 1.496

Rp 5.443

Rp 51.289

Rp 12.452.558.888

Rp $\quad 36.740 .873$

$\underline{\operatorname{Rp} \quad 4.393 .352 .845}$

Rp 16.845.911.733

Jumlah biaya departemen pembuatan

Sumber: PT. Sariwangi A.E.A (Data Diolah, 2016)

\section{Perhitungan Harga Pokok Proses Periode April-Juni 2016}

1. Data Produksi Teh Sedap Wangi

Tabel 12. Data Produksi Teh Sedap Wangi Periode April-Juni

\begin{tabular}{lc}
\hline \multicolumn{1}{c}{ Keterangan } & Departemen Pembuatan \\
\hline Barang dalam proses awal & 21.256 FIB \\
Produk yang dimasukkan dalam proses & 452.252 FIB \\
Barang selesai di transfer ke gudang & 339.189 FIB \\
Barang dalam proses akhir & 127.535 FIB \\
Produk Hilang di akhir proses & 6.784 FIB \\
\hline Sumber: PT. Sariwangi A.E.A (Data diolah,2016)
\end{tabular}


diperoleh harga pokok produksi sebesar Rp $\quad 48.004$

Tabel 16 Laporan Biaya Produksi Periode April-Juni

PT. Sariwangi A.E.A

Laporan Biaya Produksi

Periode April- Juni 2016

Data Produksi

Barang dalam proses awal

21.256 FI

Barang yang dimasukkan dalam proses

Produk jadi yang ditransfer ke gudang

339.189 FIB

$452.252 \mathrm{FI}$

Produk dalam proses akhir bulan, dengan tingkat penyelesaian

Biaya BB 100 \%dan penolong $50 \%$ biaya 127.535 FIB

Konversi 75\%

Produk yang hilang pada awal proses

Biaya yang dibebankan dalam departemen pembuatan:

Biaya bahan baku

Biaya bahan penolong

Biaya tenaga kerja

Biaya overhead pabrik

Jumlah biaya produksi departemen pembuatan

Total

Rp 20.600 .912 .556

Rp. $\quad 363.180 .636$

Rp $\quad 601.828 .668$

Rp $\quad 1.633 .602 .600$

Rp 23.199.524.457 $\underline{473.508 \mathrm{FIB}}$

Per Kg

Rp 43.507

Rp $\quad 767$

Rp 1.271

Rp 3.450

Rp 51.289

Perhitungan Biaya

Harga pokok produk selesai yang ditransfer ke gudang

Harga pokok persediaan produk dalam proses pada akhir periode

Biaya bahan baku

Biaya bahan penolong

Biaya tenaga kerja

Biaya overhead pabrik

Rp $\quad 5.548 .665 .245$

Rp $\quad 48.909 .672,5$

Rp $\quad 121.572 .739$

Rp $\quad 329.996 .812,5$

Rp 16.618.565.055

Rp $\quad 6.049 .144 .469$

Rp 22.730.709.524

Jumlah biaya departemen pembuatan

Sumber: PT. Sariwangi A.E.A (Data diolah, 2016)

Perhitungan Harga Pokok Proses Periode 1. Data Produksi Teh Sedap Wangi
Juli-September 2016

Tabel 17 Data Produksi Teh Sedap Wangi Periode Juli-September

\begin{tabular}{lc}
\hline \multicolumn{1}{c}{ Keterangan } & Departemen Pembuatan \\
\hline Barang dalam proses awal & 12.872 FIB \\
Produk yang dimasukkan dalam proses & 273.873 FIB \\
Barang selesai di transfer ke gudang & 205.405 FIB \\
Barang dalam proses akhir & 77.232 FIB \\
Produk Hilang di dalam proses & 4.108 FIB \\
\hline
\end{tabular}

Sumber: PT. Sariwangi A.E.A (Data diolah,2016)

Berdasarkan data produksi teh sedap wangi diatas dapat dilihat bahwa produksi teh sedap wangi mengalami Penurunan dari quartil sebelumnya karena pada quartil ini permintaan akan produk teh sedap wangi menurun. Barang dalam proses awal 12.872 FIB produk yang dimasukkan dalam proses adalah sebanyak 273.873 FIB, barang jadi yang

ditransfer ke gudang FG (finished good) sebanyak 205.405 FIB, barang dalam proses akhir sebanyak 77.232 FIB dan produk hilang sebanyak 4.108 FIB.

2. Perhitungan Unit Ekuivalensi

Dalam menentukan metode harga pokok proses dibutuhkan perhitungan unit 
ekuivalensi. Berikut ini perhitungan unit ekuivalensi pada PT. Sariwangi A.E.A. Tabel 18 Perhitungan Unit Ekuivalensi Periode Juli-September

\begin{tabular}{|c|c|c|c|c|c|c|}
\hline Keterangan & \multicolumn{2}{|c|}{$\begin{array}{l}\text { Biaya Bahan Baku } \\
(100 \%)\end{array}$} & $\begin{array}{l}\text { Biaya Konversi } \\
(75 \%)\end{array}$ & \multicolumn{3}{|c|}{$\begin{array}{l}\text { Biaya Bahan Penolong } \\
(50 \%)\end{array}$} \\
\hline Barang selesai & 205.405 & & 205.405 & 205.405 & & \\
\hline Barang dalam proses & 77.232 & & 57.924 & 38.6 & & \\
\hline Jumlah & 282.637 & & 263.329 & & & \\
\hline \multicolumn{7}{|c|}{ 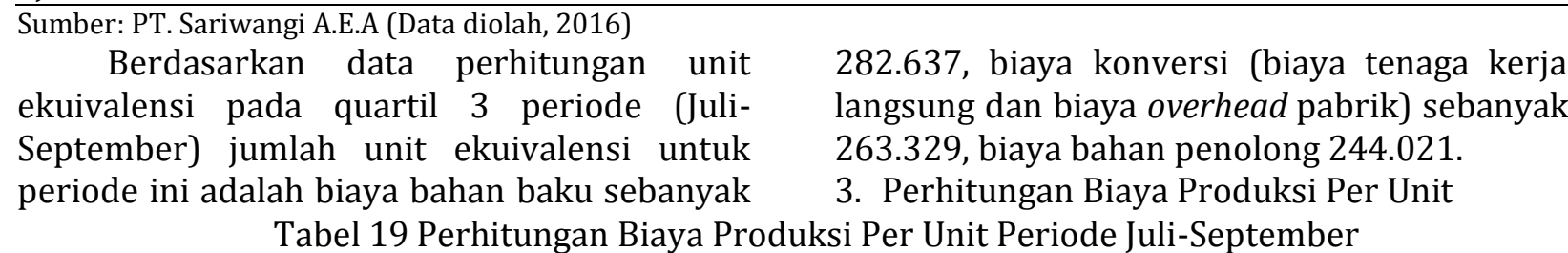 } \\
\hline Jenis Biaya & $\begin{array}{l}\text { Biaya bahan baku } \\
\text { yang melekat }\end{array}$ & & $\begin{array}{l}\text { Biaya yang } \\
\text { luarkan dalam } \\
\text { iode sekarang }\end{array}$ & $\begin{array}{l}\text { Unit } \\
\text { knuivalensi }\end{array}$ & $\begin{array}{r}\text { Biaya } \\
\text { unit pr } \\
\text { dihasi }\end{array}$ & $\begin{array}{l}\text { a per } \\
\text { roduk } \\
\text { ilkan. }\end{array}$ \\
\hline iaya baha & Rp 2.339.833.544 & $\mathrm{Rp}$ & 9.956 .762 .464 & 282.637 & & 43.507 \\
\hline iaya bahan penolong & $\mathrm{Rp} \quad 35.596 .872$ & $\mathrm{RP}$ & 151.476 .418 & 244.021 & $\mathrm{Rp}$ & 767 \\
\hline iaya tenaga kerja & 124.800 .000 & $\mathrm{Rp}$ & 338.700 .000 & 263.329 & $\mathrm{Rp}$ & 1.760 \\
\hline Biaya overhead pabrik & 305.306 .940 & $\mathrm{Rp}$ & 1.421 .723 .935 & 263.329 & $\mathrm{Rp}$ & 6.808 \\
\hline Jumlah & Rp 2.805.537.356 & & 11.868.662.817 & 1.044 .700 & $\mathrm{Rp}$ & 52.842 \\
\hline
\end{tabular}

Sumber: PT. Sariwangi A.E.A (Data diolah, 2016)

Berdasarkan perhitungan biaya per unit

teh sedap wangi periode Juli-September 2016 dapat dijelaskan bahwa biaya per unit untuk bahan baku adalah sebesar Rp 43.507, biaya bahan penolong sebesar Rp 767, biaya tenaga

kerja langsung sebesar Rp 1.760 dan biaya overhead pabrik sebesar Rp 6.808 jadi biaya produksi unit pada quartil 3 adalah Rp 52.842.
4. Perhitungan
Biaya
Produksi

Tabel 20 Perhitungan Biaya Produksi Periode Juli-September

\begin{tabular}{|c|c|}
\hline rrga pokok Produk jadi & \\
\hline$(77.232$ FIB $)$ & \\
\hline Biaya Bahan Baku $(100 \% \times 77.232) \times 45.583=$ & Rp 3.360.132.624 \\
\hline ng $(50 \% \times 77.232) \times 7$ & $\mathrm{Rp} \quad 29.618 .472$ \\
\hline Biaya tenaga kerja & 101.946.240 \\
\hline Biaya overhead pabrik $(75 \% \times 77.232) \times 6.808=$ & 394.346 .592 \\
\hline
\end{tabular}

Jumlah Biaya Produksi Rp 10.854.011.010 Sumber: PT. Sariwangi A.E.A (Data diolah, 2016)

Berdasarkan data diatas dapat dilihat bahwa jumlah biaya produksi sebesar Rp 14.240.054.938 dibagi dengan hasil produksi

sebanyak 286.745 dapat diperoleh harga pokok produksi sebesar Rp 49.661

Tabel 21 Laporan Biaya Produksi Periode Juli- September

PT. Sariwangi A.E.A

Laporan Biaya Produksi

Periode Juli- September 2016

Data Produksi
Barang dalam proses awal
Barang yang dimasukkan dalam proses
Produk jadi yang ditransfer ke gudang
Produk dalam proses akhir bulan, dengan tingkat
penyelesaian
$\quad$ Biaya BB 100 \%dan penolong 50\% biaya
Konversi 75\%
$\quad$ Produk yang hilang pada awal proses

Rp $\quad 3.386 .043 .928$

Rp 14.240.054.938 
Biaya yang dibebankan dalam departemen pembuatan:

Biaya bahan baku

Biaya bahan penolong

Biaya tenaga kerja

Biaya overhead pabrik

Jumlah biaya produksi departemen pembuatan

Perhitungan Biaya

Harga pokok produk selesai yang ditransfer ke gudang

Harga pokok persediaan produk dalam proses pada akhir periode

Biaya bahan baku

Biaya bahan penolong

Biaya tenaga kerja

Total

Rp $\quad 12.475 .414 .715$

Per Kg

Rp 219.933.415

Rp 43.507

Rp $\quad 504.671 .200$

Rp $\quad 767$

Rp $\quad 1.952 .159 .960$

Rp $\quad 1.760$

Rp 15.152.179.290

Rp 6.808

Rp 52.842

Biaya overhead pabrik

Rp 3.360.132.624

Rp $\quad 29.618 .472$

Rp $\quad 101.946 .240$

Rp $\quad 394.346 .592$

Rp 10.854.011.010

Jumlah biaya departemen pembuatan

Sumber: PT. Sariwangi A.E.A (Data diolah, 2016)

\section{Perhitungan Harga Pokok Proses Periode Oktober-Desember 2016 \\ 1. Data Produksi Teh Sedap Wangi}

2.

Tabel 22 Data Produksi Teh Sedap Wangi Periode Oktober-Desember

\begin{tabular}{lc}
\hline \multicolumn{1}{c}{ Keterangan } & Departemen Pembuatan \\
\hline Barang dalam proses awal & 6.718 FIB \\
Produk yang dimasukkan dalam proses & 142.943 FIB \\
Barang selesai di transfer ke gudang & 107.207 FIB \\
Barang dalam proses akhir & 40.310 FIB \\
Produk Hilang di akhir proses & 2.144 FIB \\
\hline
\end{tabular}

Sumber: PT. Sariwangi A.E.A (Data diolah,2016)

Berdasarkan data produksi teh sedap wangi diatas dapat dilihat bahwa produksi teh sedap wangi mengalami Penurunan dari quartil sebelumnya karena pada quartil ini permintaan akan produk teh sedap wangi menurun. barang dalam proses awal produk yang dimasukkan dalam proses adalah sebanyak 142.943 FIB, barang jadi yang ditransfer ke gudang FG (finished good)

Tabel 23 Perhitungan Unit Ekuivalensi Periode Oktober-Desember

\begin{tabular}{lccc}
\hline \multicolumn{1}{c}{ Keterangan } & Biaya Bahan Baku & Biaya Konversi & Biaya Bahan Penolong \\
& $(100 \%)$ & $(75 \%)$ & $(50 \%)$ \\
\hline Barang selesai & 107.207 & 107.207 & 107.207 \\
Barang dalam proses & 40.310 & $30.232,5$ & 20.155 \\
\hline Jumlah & 147.517 & $137.439,5$ & 127.362 \\
\hline
\end{tabular}

Sumber: PT. Sariwangi A.E.A (Data diolah, 2016)

Berdasarkan data perhitungan unit ekuivalensi pada quartil 4 periode (OktoberDesember) jumlah unit ekuivalensi untuk periode ini adalah biaya bahan baku sebanyak periode ini adalah biaya bahan baku sebanyak 4. Perhitungan Biaya Produksi
Tabel 24 Perhitungan Biaya Produksi Per Unit Periode Oktober-Desember sebanyak 107.207 FIB, barang dalam proses akhir sebanyak 40.310 FIB dan produk hilang sebanyak 2.144 FIB.

3. Perhitungan Unit Ekuivalensi

Dalam menentukan metode harga pokok proses dibutuhkan perhitungan unit ekuivalensi. Berikut ini perhitungan unit ekuivalensi pada PT. Sariwangi A.E.A.

$\begin{array}{llll}\text { Jenis Biaya } & \text { Biaya bahan baku } & \text { Biaya yang } & \text { Unit }\end{array}$




\begin{tabular}{|c|c|c|c|c|}
\hline & yang melekat & $\begin{array}{l}\text { dikeluarkan dalam } \\
\text { periode sekarang }\end{array}$ & Ekuivalensi & $\begin{array}{c}\text { produk } \\
\text { dihasilkan. }\end{array}$ \\
\hline Biaya bahan baku & Rp 1.221.250.597 & Rp 5.196 .749 .942 & 147.517 & Rp 43.507 \\
\hline $\begin{array}{l}\text { Biaya bahan } \\
\text { penolong }\end{array}$ & $\mathrm{Rp} \quad 18.579 .399$ & $\mathrm{RP} \quad 79.060 .344$ & 127.362 & 767 \\
\hline Biaya tenaga kerja & 115.860 .000 & 319.860 .000 & $137.439,5$ & 3.170 \\
\hline $\begin{array}{l}\text { Biaya overhead } \\
\text { pabrik }\end{array}$ & 232.154 .182 & $\mathrm{Rp} \quad 1.009 .366 .012$ & $137.439,5$ & 9.033 \\
\hline Jumlah & Rp 1.587.844.178 & Rp $\quad 6.605 .036 .298$ & $566.438,5$ & Rp 56.477 \\
\hline
\end{tabular}

Berdasarkan perhitungan biaya per unit

teh sedapwangi periode Oktober-Desember 2016 dapat dijelaskan bahwa biaya per unit untuk bahan baku adalah sebesar Rp 43.507, biaya bahan penolong sebesar Rp 767, biaya

tenaga kerja langsung sebesar Rp 3.170 dan biaya overhead pabrik sebesar Rp 9.033 jadi biaya produksi per unit pada quartil 4 adalah Rp 56.477.

5. Perhitungan Biaya Produksi.

Tabel 25Perhitungan Biaya Produksi Periode Oktober-Desember

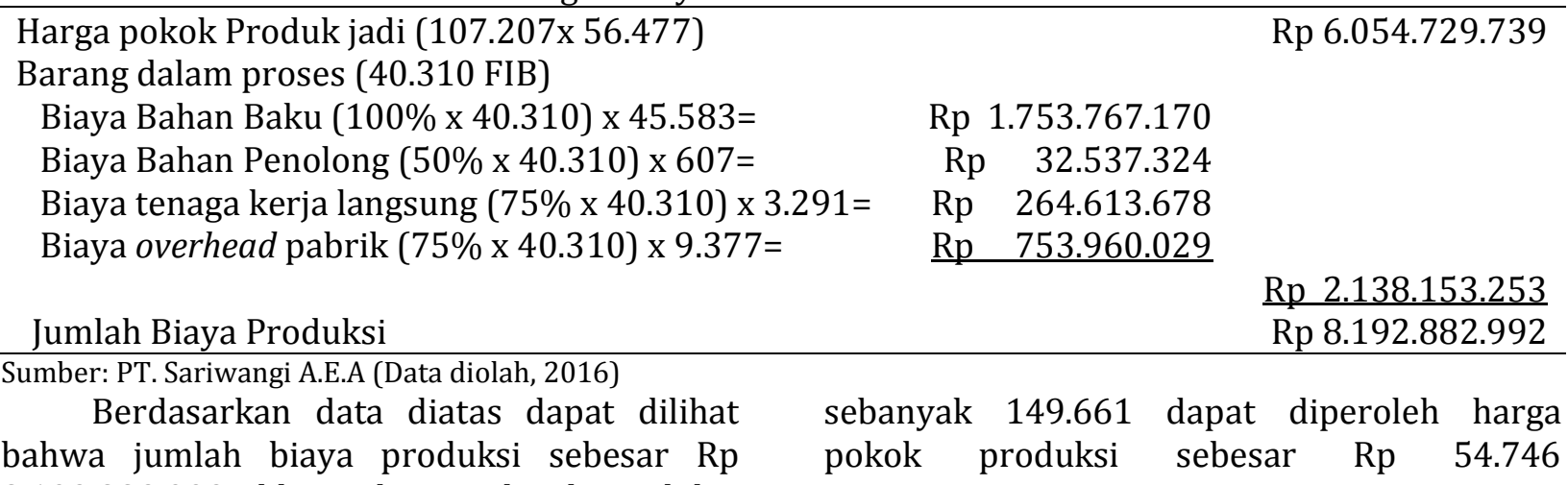
8.192.882.992 dibagi dengan hasil produksi

Tabel 26 Laporan Biaya Produksi Periode Oktober-Desember

PT. Sariwangi A.E.A

Laporan Biaya Produksi

Periode Okteober-Desember 2016

Data Produksi

Barang dalam proses awal

$6.718 \mathrm{FI}$

Barang yang dimasukkan dalam proses

Produk jadi yang ditransfer ke gudang

$142.943 \mathrm{FI}$

Produk dalam proses akhir bulan, dengan

tingkat penyelesaian

Biaya BB $100 \%$ dan penolong $50 \%$ biaya

Konversi $75 \%$

Produk yang hilang pada awal proses

107.207 FIB

Biaya yang dibebankan dalam departemen pembuatan:

Biaya bahan baku

Biaya bahan penolong

Biaya tenaga kerja

Biaya overhead pabrik

$40.310 \quad$ FIB

$\underline{2.144 \quad F I B}$

$\underline{149.661 \mathrm{FIB}}$

Jumlah biaya produksi departemen pembuatan

Perhitungan Biaya

Harga pokok produk selesai yang ditransfer ke gudang

$\begin{array}{lrrrr} & \text { Total } & & \text { Per Kg } \\ \text { Rp } & 6.511 .301 .127 & & \text { Rp } & 43.507 \\ \mathrm{Rp} . & 114.789 .987 & & \mathrm{Rp} & 767 \\ \mathrm{Rp} & 474.425 .370 & & \mathrm{Rp} & 3.170 \\ \mathrm{Rp} & 1.351 .887 .813 & & \text { Rp } & 9.033 \\ \mathrm{Rp} & 8.452 .404 .297 & & & \mathrm{Rp} 56.477\end{array}$

Rp 6.054.729.739 
Harga pokok persediaan produk dalam proses pada akhir periode

Biaya bahan baku

Biaya bahan penolong

Biaya tenaga kerja

Biaya overhead pabrik

Rp $\quad 1.753 .767 .170$

Rp $\quad 15.458 .885$

Rp 95.837.025

Rp 273.090.172,5

Rp 2.138.153.253

Rp 8.192.882.992

Jumlah biaya departemen pembuatan

Sumber: PT. Sariwangi A.E.A (Data diolah, 2016)

\section{KESIMPULAN}

Berdasarkan hasil analisis dan pembahasan yang telah diuraikan, pada penelitiian ini dapat ditarik kesimpulan bahwa:

1. Hasil dari perhitungan harga pokok produksi pada PT. Sariwangi A.E.A adalah Perhitungan harga pokok produksi untuk teh sedapwangi quartil 1 periode (JanuariMaret) 2016 adalah sebesar Rp 49.750, quartil 2 periode (April-Juni) 2016 adalah sebesar Rp 48.004, quartil 3 periode (JuliSeptember) 2016 sebesar Rp 49.661, dan quarti 4 periode (Oktober-Desember) 2016 adalah sebesar Rp Rp 54.742. Berdasarkan perhitungan harga pokok produksi teh sedapwangi per quartil periode tahun 2016, harga pokok produksi tertinggi terjadi pada quartil 4 dikarenakan hasil produksi yang rendah dan pembebanan biaya yang terlalu tinggi dalam periode tersebut.

2. Faktor yang mempengaruhi pengumpulan metode harga pokok proses adalah pengaruh produk hilang dalam proses dan pembebanan biaya yang terlalu tinggi. Produk hilang dikatakan sebagai faktor yang mempengaruhi karena akan mengurangi hasil produksi, sedangkan pembebanan biaya dikatakan sebagai faktor yang mempengaruhi karena dengan hasil produksi yang menurun biaya yang dikeluarkan relatif sama maka akan mempengaruhi perhitungan harga pokok proses.

3. Pengumpulan harga pokok produksi teh sedapwangi dengan menggunakan metode harga pokok proses menghasilkan harga pokok produksi pada quartil 1 periode (Januari-Maret) 2016 adalah Rp 49.750 per FIB/dus, pada quartil ke 2 Periode (AprilJuni) 2016 adalah Rp 48.004, pada quartil ke 3 periode (Juli-September) 2016 adalah Rp 49.661 dan pada quartil 4 periode adalah Rp 54.742. Berdasarkan perhitungan harga pokok produksi dengan menggunakan metode harga pokok proses akan menghasilkan harga pokok yang sama bila diperhitungkan karena biaya yang dikumpulkan dalam departemen produksi akan diperhitungkan dalam perhitungan harga pokok produksi dan akan menghasilkan harga pokok produk yang sama.

\section{DAFTAR PUSTAKA}

Abdullah, Firdaus Ahmad Dunia dan Wasilah, 2009, Akuntansi Biaya, Salemba Empat Jakarta.

Bustami, Bastian \& Nurlaela, 2007, Akuntansi Biaya, Edisi Pertama, Penerbit Graha Imu, Yogyakarta.

Carter, William K, 2009, Akuntansi Biaya, di terjemahkan oleh Krista Buku 1, Edisi 14, Salemba Empat, Jakarta.

Darsono, Prawironegoro, 2005. Akuntansi Manajemen, Jakarta, Diadit Media.

Hidayati, Nur Hasanah, 2010, Evaluasi Penentuan Harga Pokok Produksi Roti Kecik Dengan Metode Harga Pokok Proses Pada Perusahaan Roti Ganep's Tradisi Solo, Skripsi Sarjana, Fakultas Ekonomi Universitas Sebelas Maret, Surakarta.

Hery, 2013, Akuntansi Dasar 1 dan 2, Cetakan Pertama, Grasindo, Jakarta.

Horngren, et al, 2005, Akuntansi Biaya Manajerial, Edisi Kesebelas, alih bahasa Desi Adharini, PT. Indeks Kelompok Gramedia, Jakarta. 
Hansen, Don R. Maryanne M. Mowen, 2000, Akuntansi Manajemen, Edisi Kedua, terjemahan A. Hermawan, Penerbit Erlanggan, Jakarta.

Harahap, Sofyan Syafri, 2003, Teori Akuntansi, PT. Raja Grafindo Persada, Jakarta.

Kuntoro, Ronny, 2005, Metode Penelitian, PPM, Jakarta.

Kuswadi, 2005, Meningkatkan Laba Melalui Pendekatan Akuntansi Keuangan dan Akuntansi Biaya, PT. Elex Media Komputindo, Jakarta.

Lasena, Siti Rahmi, 2013, Analisis Penentuan Harga Pokok Produksi Pada PT. Dimembe Nyiur Agripro, Fakultas Ekonomi Universitas Sam Ratulangi, Jurnal Emba, Vol 1, No 3, Juni, halaman 585- 592, Manado.

Michael, Suharli, 2006, Akuntansi untuk Bisnis Jasa dan Dagang, Edisi 1, Graha Ilmu, Yogyakarta.

Mulyadi, 2016, AkuntansiBiaya, Edisi Kelima, Salemba Empat, Jakarta.

Marbun, B.N, 2003, Kamus Manajemen, Pustaka Sinar Harapan, Jakarta.

Mursyidi, 2008, Akuntansi Biaya, Edisi Satu, Refika Aditama, Bandung.

Pamela, Rika, 2009, Evaluasi Harga Pokok Produksi Lembar Kerja Siswa (LKS) Dengan Metode Harga Pokok Proses Pada CV Hasan Pratama, Skripsi Sarjana, Fakultas Ekonomi Universitas Sebelas Maret, Surakarta.

Purwaji, Agus dan Wibowo, 2009, Akuntansi Biaya, Edisi Pertama, Salemba Empat , Jakarta.
Reeve, James et all2009, Principles of accounting-Indonesia

Adaptation, diterjermahkan oleh Ersa Tri Wahyuni Dkk, Pengantar Akuntansi Adaptasi Indonesia,Buku 1, Salemba Empat, Jakarta.

Riahi, Ahmed, 2011, Teori Akuntansi. Cetakan Kelima, Salemba Empat, Jakarta.

Soemarso, 2004, Akuntansi Sebagai Jakarta.

Pengantar, Salemba Empat,

Sugiyono, 2013, Metode Penelitian

Kombinasi (Mixed Methods),

Alfabeta, Bandung.

Suhayati, Ely dan Sri Dewi Anggadini, 2005, Pengantar Akuntansi I, UNIKOM, Bandung.

Suprajitno, Dwi, 2011, Analisis Perhitungan

Harga Pokok Produksi

Dengan Metode Harga Pokok Proses

Pada Perusahaan Soun Cap

Ketela Tambak, Fakultas Ekonomi STIE Putra Bangsa, Jurnal Fokus

Bisnis Volume 10 No1, Juli. Jawa Tengah

Supriyono, 2000, Akuntansi Biaya, Buku 1, Edisi dua, Yogyakarta, BPFE.

Suyadi, Prawirosentono, 2000, Manajemen Operasi Analisis dan Studi Kasus, Edisi Ketiga, Bumi Aksara, Jakarta.

Simamora, Henry, 2002, Akuntansi Manajemen, Jakarta, Salemba Empat.

Warindrani, Krisna, 2006, Akuntansi Manajemen, Cetakan

Pertama, Graha Ilmu, Yogyakarta. 